\title{
Reflexões epistemológicas sobre uma relação: o cinema argentino \& as memórias da ditadura militar
}

\section{Epistemological reflections on a relationship: the argentine cinema \& the memories of the military dictatorship}

Salatiel Ribeiro Gomes ${ }^{1}$

\begin{abstract}
Resumo
No presente artigo, lançamos mão de alguns pressupostos da relação filme-história-memória para tecer uma reflexão de cunho epistemológico sobre o valor político do cinema, tomando como objeto a cinematografia argentina que trata a memória da última ditadura militar, com abordagem de seu discurso, sua linguagem cinematográfica e seus diferentes posicionamentos nos embates que marcam aquela sociedade. Na oportunidade, fazemos uma breve discussão sobre os conceitos de memória e as possibilidades metodológicas que servem à leitura dos filmes pelos estudos históricos.
\end{abstract}

Palavras-chave: ditadura; cinema; memória; Argentina.

\begin{abstract}
In this article, we used some assumptions regarding the film-history-memory to weave a epistemological reflection on the political value of the cinema, taking as object the argentine film about the memory of the last military dictatorship. On occasion, we make a brief discussion of the concepts of memory and on methodological possibilities that serve the reading of films by historical studies.
\end{abstract}

Keywords: dictatorship; cinema; memory; Argentina.

Artigo recebido em: 30 /01/2015.

Artigo aceito para publicação em: 21/06/2015.

\footnotetext{
${ }^{1}$ Doutor em História pela Universidade de Brasília e Professor do Centro Universitário de Brasília. Email: salatiel.gomes@uniceub.br e salatiel_ribeiro@hotmail.com
}

\section{GANPHLAC}

Revista Eletrônica da ANPHLAC, ISSN 1679-1061, №. 18, p. 287-304, jan./jul. 2015. 


\section{O cinema e seu valor político}

Fazer do gigantesco aparelho técnico do nosso tempo o objeto das inervações humanas - é essa a tarefa histórica cuja realização dá ao cinema o seu verdadeiro sentido.

Walter Benjamin

Quando, nas primeiras décadas do século passado, se fez comum desconfiar do cinema e acusá-lo de ser um mecanismo de alienação que convertia o público em uma massa passiva e homogênea, Benjamin foi um dos primeiros a chamar atenção para a importância social e política deste recurso. ${ }^{2} \mathrm{Na}$ contramão dos que ridicularizavam o cinema, ele acreditava ser progressista o choque epistemológico do grande aparelho, cujos modos de representação e percepção refletiam novas forças históricas. O método usado pelo cinematógrafo, segundo o filósofo, por um lado torna visível "os mil condicionamentos que determinam nossa existência, e por outro assegura-nos um grande e insuspeitado espaço de liberdade" (BENJAMIN, 1994, p. 189). Com isso, assinalava a capacidade do aparelho de ampliar, por assim dizer, tanto o domínio da percepção quanto a consciência crítica do espectador. A produção cinematográfica do século XX atesta a tese benjaminiana de que a aniquilação da aura, da função contemplativa e de culto da obra de arte, em face das técnicas modernas de reprodutibilidade - da qual o cinematógrafo é o maior representante -, deu a ela (obra de arte) um caráter profundamente novo, que a institui, a partir daí, na práxis política, e não mais ritual. Stam, desdobrando a postura do filósofo em relação às possibilidades políticas do cinema, enfatiza:

Benjamin transformou a tão criticada "distração" da experiência cinematográfica em uma vantagem cognitiva. A distração não implicava passividade; era, em lugar disso, uma manifestação liberatória da

\footnotetext{
${ }^{2}$ Chamamos de cinema a instituição cinematográfica, o conjunto de filmes com seus procedimentos fílmicos e não-fílmicos; e filme, por seu turno, ao discurso localizável, à narrativa, considerando que ele (o filme) tem a própria instituição cinematográfica como parte constituinte. Por isso, por vezes, usaremos aqui o termo cinema para nos referirmos a um plural de filmes e, algumas vezes, usaremos filme para dizer cinema, sem prejuízo do seu significado contextual.
}

\section{CANPHLAC}

Revista Eletrônica da ANPHLAC, ISSN 1679-1061, №. 18, p. 287-304, jan./jul. 2015. 
consciência coletiva, um sinal de que o espectador não estava "enfeitiçado na escuridão". [...] Em contraste com a absorção solitária provocada pela leitura de um romance, a espectatorialidade cinematográfica era necessariamente gregária, além de potencialmente crítica e interativa (STAM, 2003, p. 85).

A crença aí era a de que o cinema teria o poder de transformar e potencializar a capacidade de ação das massas na direção de uma ruptura revolucionária. Muito embora Benjamin tivesse em mente fazer frente ao fascismo, seu otimismo é reterritorializado em contextos posteriores, como o vemos nos intelectuais-cineastas dos chamados países subdesenvolvidos, os quais, na década de 60, investiram em uma estética cinematográfica politicamente engajada e consciente ${ }^{3}$ ou ainda, em tempos mais recentes, na ideia de que, mediante a projeção de sonhos coletivos, o cinema pudesse libertar a nós e aos mortos da solidão, e fazer do passado um vir a ser constante - como descreve, alegoricamente, o argentino Eliseo Subiela, em seu filme No te Mueras sin Decirme Adonde Vas (1995), ${ }^{4}$ entre outros.

Ferro, em seu estudo sobre a relação Cinema \& História, observa que, desde que se consolidou como arte, o cinema permitiu que seus pioneiros interviessem na história com filmes de ficção e documentários, que, "sob a aparência de representação, doutrinam e glorificam" (FERRO, 1992, p. 13). Em vista do realismo que emana das imagens-movimento e do poder de representar o mundo e (co)mover o espectador, os governantes muito cedo perceberam a importância do cinema e buscaram apropriar-se dele e submetê-lo a seus próprios interesses. Essa apropriação se dá de duas formas. Na primeira delas, o cinema participa na edificação da imagem do Estado ou de um regime político, como foi o exemplo da propaganda nazista em filmes como O Eterno Judeu (1940), de Fritz Hippler, e O Triunfo da Vontade (1936), de Leni Riefenstahl. Na segunda forma, o Estado intervém no âmbito da

\footnotetext{
${ }^{3}$ Como foi o caso, no Brasil, de Glauber Rocha e outros cineastas do movimento Cinema Novo, e, na Argentina, do Cine Liberación, fundado por Fernando Solanas e outros.

${ }^{4}$ Lançado em 1995, quando da retomada dos embates por justiça aos desaparecidos na Argentina, No te Mueras sin Decirme Adonde Vas enquadra-se no que se conhece como "metacinema". Trata-se de um filme sobre o cinema, e que o exalta como um instrumento/elemento capaz de suturar o vínculo entre os mortos e os vivos. Na trama, um aparelho inventado pelo protagonista Leopoldo captura os sonhos e os projeta em forma de imagemmovimento, de forma a dar materialidade a experiências até então recalcadas, a coisas mortas subjetivadas pelo sonhador. O conteúdo desses presumíveis sonhos, conforme se pode apreender do filme, é sempre um objeto perdido pelo sonhador, que até então se mantinha oculto no inconsciente: do melancólico Leopoldo, o invento capta e projeta imagens de pessoas que morreram. Por esse intermédio, a existência virtual dos mortos entre os vivos ganha uma dimensão imagética.
}

\section{CANPHLAC}

Revista Eletrônica da ANPHLAC, ISSN 1679-1061, №. 18, p. 287-304, jan./jul. 2015. 
produção cinematográfica ao lançar mão da censura, da regulação da atividade comercial ou mesmo com o financiamento e a proteção do mercado a que corresponde.

Ambas as formas são verdadeiras na história do cinema na Argentina. Primeiramente, é conhecido que, desde o primeiro peronismo, o Estado é condição necessária para que exista cinema argentino, uma vez que este não se sustentaria sem o subsídio estatal, em razão tanto do tamanho do seu mercado de consumo interno quanto da concorrência de filmes estrangeiros. ${ }^{5}$ Ademais, tal e qual fazia o peronismo, algumas produções elaboradas para louvar o golpe militar de 1976 afinavam-se, do ponto de vista do procedimento, ao modelo dos filmes de propaganda dos regimes fascistas europeus - como é o exemplo do curta-metragem Ganamos la Paz (1976), de Francisco Javier Mendonza. ${ }^{6}$

Para além dessas apropriações, a previsão de que o cinema, com a popularização do meio de produção, se tornaria "ainda mais ativo como agente de uma tomada de consciência social” (FERRO, 1992, p. 15), também fez-se realidade na Argentina, a partir da década de 80, quando amigos e parentes de desaparecidos encontraram nele um instrumento para inserir as questões do passado recente entre as demandas do presente e uma ferramenta de luta contra a impunidade institucionalizada pelos dois primeiros presidentes democráticos - Alfonsín e Menem. ${ }^{7}$ Isso encontra relação de sentido nas proposições deste autor, quando, reportando-se a um fenômeno talvez semelhante ao aí descrito, observa que o cinema demonstra para o

\footnotetext{
${ }^{5}$ Para saber mais sobre a relação entre o cinema e o Estado argentino, vide de Judith Gociol e Hernán Invernizzi, Cine y ditadura: la censura al desnudo (Buenos Aires: Capital intelectual, 2006), e de Clara Kriger, Cine y peronismo: el estado em escena (Buenos Aires: Siglo Veintiuno Editores, 2009).

${ }^{6}$ Esse filme - espécie de propaganda produzida para louvar o novo regime - é bastante sintomático tanto em relação às estratégias iniciais que os generais adotaram para convencer a opinião pública quanto a seu objetivo de erradicação da desordem. Construído num estilo documental expositivo, chama a atenção nesse filme a tentativa de desvencilhar a imagem de Juan Domingo Perón da dos guerrilheiros, enfatizando-se os momentos de atrito e as ações que o desagradaram e que tornaram irreconciliável sua relação com os grupos armados que havia liderado do exílio, como exemplifica esta fala do narrador over: "Los grupos subversivos, que en otros tiempos él había alentado, [...] se van de la plaza, y trazan un evidente enfrentamiento con el gobierno legal. Acentúa la subversión marxista su accionar."

${ }^{7}$ Faz-se referência aí às leis promulgadas pelo presidente Alfonsín, que tornavam impunes os crimes praticados durante a ditadura (A Ley del punto final, 23.492/86, colocava um fim aos processos judiciais contra os militares acusados, e a Ley de la obediencia debida, 23.521/87, imunizava os militares de escalões inferiores), e aos indultos concedidos por Carlos Menem, que absolviam os militares já condenados que não haviam sido beneficiados por aquelas leis: Decreto 1002/89, que indulta os chefes militares não beneficiados pelas leis de Ponto Final e Obediência Devida; Decreto 1003/89, indulta os guerrilheiros, a maioria deles mortos e desaparecidos; Decreto 1004/89, indulta os militares "carapintadas", que se sublevaram no governo anterior; Decreto 1005/89, indulta os comandantes militares condenados por delitos cometidos na condução da guerra das Malvinas; Decreto 2741/90, indulta comandantes das juntas militares, que haviam sido condenados em 1985; Decreto 2745/90, indulta Alfredo Martínez de Hoz, condenado por participação em crime de lesa humanidade; e, entre outros, Decreto 2746/90, que indulta o militar Guillermo Suárez Mason, também condenado por crime de lesa humanidade
}

\section{GANPHLAC}

Revista Eletrônica da ANPHLAC, ISSN 1679-1061, №. 18, p. 287-304, jan./jul. 2015.

http://revista.anphlac.org.br/ 
historiador que, com uso da memória e da tradição oral, é possível devolver à sociedade "uma história da qual a instituição a tinha despossuído" (FERRO, 1992, p. 19).

$\mathrm{Na}$ Argentina, se aceitarmos que os atos de memórias têm sua parcela de responsabilidade pela retomada dos julgamentos aos envolvidos na barbárie praticada durante a última ditadura, como pretende Sarlo (2007), é coerente também atribuir parte dessa responsabilidade ao cinema, em seu encontro com aqueles atos. Isso traz à emergência a relação entre cinema e história, porque a leitura cinematográfica do passado aí feita expõe para nós, historiadores, questões relacionadas ao modo como também lemos o passado e, por sua vez, reitera a importância política do cinema.

O valor político do cinema reside também na capacidade de mobilizar as camadas profundas da experiência, o que supõe, nas palavras de Rouanet, "que o espectador mantenha intacta sua capacidade de pensar, de associar e de rememorar" (ROUANET, 1990, p. 62). O trabalho associativo que o cinema requer fica a cargo da memória. Como exemplo, o valor político dos filmes de Eisenstein, segundo Rouanet, estaria menos na mensagem direta que no apelo à habilidade associativa do espectador. Esse, para tanto, opera tais associações com uso "de suas leituras passadas, com sua práxis política presente, com sua biografia pulsional, com toda riqueza de sua própria história" (ROUANET, 1990, p. 62). ${ }^{8}$

É o caso também dos filmes Juan Como si Nada Hubiera Sucedido (1987), de Carlos Echeverria, e Un Muro de Silencio (1993), de Lita Stantic, entre outros, cujo conteúdo político não apenas pressupõe tal capacidade por parte do espectador como também a incita, exigindo dele a formulação de um juízo crítico, a partir das possíveis reminiscências que as imagens provocam. ${ }^{9}$ Nesses dois filmes, o recurso estético adotado é o que permite interpelar o outro, o espectador. Para tanto, ambos os cineastas lançam mão de uma operação análoga aos documentários reflexivos - exposição dos elementos da filmagem, do extracampo, do processo de produção, entre outras características -, recurso que, ao mesmo tempo que

\footnotetext{
${ }^{8}$ Não obstante, muito embora Rouanet esteja ali se referindo a um modelo específico de cinema, acreditamos que tanto as produções classificadas como "cinema-arte" ou "cinema de autor" quanto os filmes "comerciais" não se desvinculam de uma dimensão fundamentalmente política.

${ }^{9}$ Juan Como se Nada Hubiera Sucedido foi produzido no contexto em que as esperanças depositadas na democracia foram solapadas pelas leis promulgadas pelo presidente Alfonsín, as quais ficaram conhecidas, no jargão popular, como "leis do esquecimento", e nos faz acompanhar o trabalho de um jornalista que investiga o caso real de desaparecimento do estudante de Direito Juan Marcos Herman, ocorrido no ano 1977 em Bariloche (único caso registrado na localidade), após seu sequestro por um comando militar. Por sua vez, Un Muro de Silencio, escrito a partir da história real da diretora Lita Stantic, aborda o drama da mulher de um desaparecido, a qual é levada a reencarar o passado quando uma equipe de cinema resolve contar a sua história.
}

\section{GANPHLAC}

Revista Eletrônica da ANPHLAC, ISSN 1679-1061, №. 18, p. 287-304, jan./jul. 2015. 
denuncia a dificuldade em transpor para a narrativa, para a instância do simbólico, a experiência traumática, arranca o espectador de sua posição passiva e o compromete. ${ }^{10}$

Para além dos espetáculos que realizam, os filmes são encarados aqui como locus de memórias e construtor de representações sociais, que funcionam como um eficiente instrumento na disputa pelo privilégio de nominar as coisas, de fixar proposições acerca do mundo social e político, e, sobretudo, como um modo de enquadramento de memórias. Por meio das articulações de sentido que os filmes operam, o campo social é representado, e seus efeitos de realidade - que escondem relações de poder - são, por vezes, naturalizados.

Os códigos da linguagem cinematográfica são, pois, uma forma de constituir temporalidades e sentidos, de inventar e significar o mundo, bem como um campo de disputas de memórias. Por isso, antecipando-se à proposição formulada anos depois por Chartier (1990), de que o historiador deve partir dos próprios códigos, das formas de apropriação, das práticas e dos objetos, Ferro orientava que, na análise histórica do cinema, há que se partir da imagem, das imagens, "considerar as imagens como tais". Um filme tomado dessa forma é considerado uma imagem-objeto, o que significa dizer que seus sentidos não são apenas cinematográficos: "ele não vale somente por aquilo que testemunha, mas também pela abordagem sócio-histórica que autoriza e pelas realidades que engendra" (FERRO, 1992, p. $87)^{11}$

Metodologicamente, tomar o filme como imagem-objeto compreende perscrutar a imagem, o não-visível, especular seus possíveis sentidos por meio de uma crítica analítica, que passa pela investigação das suas condições de produção e pela decodificação das imagens e sons. A análise prescreve também a observação de recorrências (sonoras, imagéticas, verbais, temáticas) entre os filmes e entre os elementos no interior de cada filme, operação que, em vez de conduzir a um limitar-se ao filme, faz do remetimento ao exterior que o circunscreve um modo de potencializar sua compreensão. O desvio da atenção para a latência, para as significações que não habitam a superfície da imagem, encontra amparo nas palavras de Nóvoa, quando dispõe que "o inconsciente do autor [do cineasta], ou o inconsciente ideológico social assimilado por ele de modo mais ou menos inconsciente, termina se

\footnotetext{
${ }^{10}$ É uma característica comum aos filmes politicamente reflexivos provocar o envolvimento do espectador. Essas narrativas, segundo Nichols (2005, p. 169), "apontam para nós, espectadores e atores sociais, e não para os filmes, como agentes que podem fechar essa brecha entre aquilo que existe e as novas formas que desejamos para isso que existe".

${ }^{11}$ Grifo nosso.
}

\section{CANPHLAC}

Revista Eletrônica da ANPHLAC, ISSN 1679-1061, №. 18, p. 287-304, jan./jul. 2015. 
manifestando em sua película" (NÓVOA, 2009, p. 179). A coerência desse pressuposto aponta-nos a relação existente entre o imaginário coletivo e as condições de existência de uma obra cinematográfica, noção particularmente importante, na medida em que obriga o pesquisador a tomar os filmes como fenômenos da mentalidade coletiva. ${ }^{12}$

Sorlin afirma não existir receitas para a análise que envolve o cinema: "cada investigação deve, na medida em que progride, produzir suas ferramentas, as quais são adaptadas aos objetivos e somente a ele" (SORLIN, 1985, p. 129). Isso autoriza o pesquisador a lançar mão de elementos de campos diversos, como é o exemplo do aporte de categorias conceituais extraídas da psicanálise, quando as noções de recalque, luto e melancolia se fazem relevantes à compreensão dos filmes e do exterior que os possibilita, sobretudo no caso do cinema argentino em seu modo de articular o passado. ${ }^{13}$ Aí, a legitimidade da transposição de categorias psicanalíticas para o âmbito da história e da memória coletiva está ancorada em Ricoeur quando busca resposta no próprio Freud para tal questão. Nesse, lembra-nos Ricoeur, há diversas referências a situações que vão além da cena psicanalítica, seja no trabalho da lembrança ou do luto:

Essa ampliação é tanto mais esperada pelo fato de todas as situações evocadas na cura psicanalítica terem a ver com o outro, não somente aquele do 'romance familiar', mas o outro psicossocial e, por assim dizer, o outro da situação histórica (RICOEUR, 2007, p. 91).

Ainda, trabalhos do próprio Freud, como Totem e Tabu e Mal estar na civilização, entre outros, dão exemplos dessa extrapolação. Há em Ricoeur (2007) a sugestão de que a coincidência entre trabalho de luto e trabalho de lembrança ganha seu sentido pleno no âmbito da memória coletiva, muito mais do que na individual, noção que calha às investigações que questionam a persistência dos embates como sequelas deixadas pelas ditaduras militares.

Um importante indicador metodológico à análise de filmes depreende da noção de crítica presente em Benjamin (1984), segundo a qual imergir no objeto consiste em arrancá-lo de suas conexões temporais e espaciais no sentido de fazê-lo significar, o que remete à noção de alegoria que o filósofo elabora em seu trabalho sobre o barroco. O objeto alegorizado se transforma numa coisa morta, "e por isso mesmo objeto de saber: um saber que evidencia a

\footnotetext{
${ }^{12}$ Um valioso exemplo é encontrado no trabalho pioneiro de Sigfried Kracauer, que defende uma relação entre a ascensão do nazismo e o cinema alemão pré-Hitler, a obra De Caligari a Hitler: Uma história psicológica do cinema alemão (Rio de Janeiro: Jorge Zahar, 1988).

${ }^{13}$ Vide a tese de doutorado Cinema e História, Comoção e Melancolia: memórias da última ditadura militar no cinema argentino, 1985-2011 (GOMES, Salatiel Ribeiro. Universidade de Brasília, 2014).
}

\section{CANPHLAC}

Revista Eletrônica da ANPHLAC, ISSN 1679-1061, №. 18, p. 287-304, jan./jul. 2015. 
falsidade do contexto" (ROUANET, 1990, p. 20). Entregue ao alegorista, segundo Benjamin, o objeto não cessa de significar, "a coisa se transforma em algo diferente, através da coisa, o alegorista fala de algo diferente. [...] Ela é um esquema, e como esquema um objeto de saber" (BENJAMIN, 1984, p. 205-206).

A alegoria sugere que o objeto seja tomado como ruína, mas permite sua ressurreição no instante em que recebe uma significação. Essa perspectiva aniquila a crença num significado último, imanente, e faz da pluralidade de possíveis sentidos a principal característica do objeto. A noção de alegoria, segundo Gagnebin, "ressalta a impossibilidade de um sentido eterno e a necessidade de perseverar na temporalidade e na historicidade para construir significações transitórias" (GAGNEBIN, 2007, p. 38).

Aqui, a assunção dessa postura faz com que compreendamos que as imagens do cinema não carregam um sentido a priori, noção que nos permite imobilizar o conjunto de filmes ou seus fragmentos, de forma a extrair deles possibilidades de sentidos orientadas pelo objetivo de compreender a forma como o cinema argentino articula o passado. Para tanto, a análise demanda a identificação dos pontos de afrontamento, das relações de conflito que indexam as realidades construídas por esse cinema às situações que o informam e ao campo de forças em que se situa.

As imagens de um filme são um imbricar de passado e presente, observável tanto no alternar dos planos quanto na capacidade do filme de abrir o aqui e agora da sua produção, de imobilizar fragmentos do imaginário social, do fluxo que o circunscreve, tornando possível especular sobre os condicionamentos do presente que o produziu (GOMES, 2011). Esta assertiva encontra amparo no pressuposto também benjaminiano de que a arte é mimese, mas o que ela imita é o real enquanto estrutura de correspondências, e ao fazê-lo copia, simultaneamente, o véu que se coloca entre o olhar e essa estrutura (ROUANET, 1990). Por isso, à guisa de exemplo, a leitura do filme Un Muro de Silencio permite que especulemos as condições de sua emergência, seu horizonte de possibilidades, as relações de força que atravessavam o imaginário social e o sentimento pelo qual boa parte da sociedade argentina se viu acometida, quando os indultos concedidos aos militares condenados somaram-se aos "abusos de esquecimento" institucionalizado no governo anterior. O mesmo vale para os filmes mais recentes, como Cautiva (2003), de Gastón Biraben, e Aparecidos (2007), de Paco Cabezas, os quais são construídos sob novas pressões, no contexto de retomadas dos embates

\section{GANPHLAC}

Revista Eletrônica da ANPHLAC, ISSN 1679-1061, №. 18, p. 287-304, jan./jul. 2015. 
que envolve o passado, agora embalados pelo protagonismo dos filhos dos desaparecidos. ${ }^{14} \mathrm{O}$ filme Cautiva estreou no ano em que Néstor Kirchner subiu ao poder e em que a sociedade argentina, recém-saída de uma profunda crise econômica, se via obrigada a prestar contas com seus fantasmas, por força das manifestações que vinham sendo promovidas pelos grupos de direitos humanos, sobretudo a associação HIJOS, formada por filhos de desaparecidos. Certamente afetado por essa conjuntura, o filme de Biraben representa a reação desses filhos, como também a vemos em Aparecidos, o qual, produzido no formato de um thriller de terror, expõe as principais questões legadas pelo passado recente da Argentina. ${ }^{15}$

\section{Tecelão da memória}

O cinema argentino aqui objetivado ratifica a noção do cinema como arte da memória, conforme sugere Almeida (2009), uma vez que os filmes participam ativamente da memória coletiva suplementando as imagens de que o espectador se deve lembrar quando evoca e projeta o passado. Essa perspectiva ancora-se na percepção de que os filmes, de modo geral e independentemente do seu formato, costumam ser uma fonte privilegiada dos conceitos que o sujeito assimila na construção de si e na interpretação que faz do mundo, da história. A esse respeito, Almeida (2009) afirma: “o cinema, ao mesmo tempo, cria ficção e realidades históricas, em imagens agentes e potentes, e produz memória. Uma arte (no sentido atual) ao mesmo tempo um artifício [...] que produz conhecimento real e práticas de vida".

Na esteira dessa noção, é possível imaginar que na Argentina boa parte da geração atual talvez só compreenda e conheça como verdadeira a sorte dos desaparecidos graças às imagens reiteradas pelos inúmeros filmes sobre o tema, sem negar, obviamente, o trabalho desempenhado pela tradição oral, pela escola e pelas outras formas de comunicação da experiência. Com isso, pensamos que a maior força dos filmes talvez resida em sua capacidade de fornecer os modelos de percepção do mundo e as imagens que se vão imiscuir às lembranças individuais e à memória coletiva.

\footnotetext{
${ }^{14}$ Faz-se referência aí ao conjunto de forças que caracteriza a segunda metade da década de 90 e que favorece a retomada dos embates por justiça, marcada pelo surgimento da agremiação HIJOS (Hijos e hijas por la justicia contra el olvido y el esquecimiento), pelo avanço das políticas públicas de memórias e pelas mobilizações populares que forçaram a revisão das leis que indultavam os militares.

15 Sobre esse filme, vide o artigo Memória e Cinema, de Salatiel Ribeiro Gomes, disponível em (http://www.revistacontemporaneos.com.br/n12/dossie/memoria-e-cinema.pdf).
}

\section{GANPHLAC}

Revista Eletrônica da ANPHLAC, ISSN 1679-1061, №. 18, p. 287-304, jan./jul. 2015. 
Pollack (1989), referindo-se à noção de memória coletiva em Durkheim e Halbwachs, chama atenção para o fato de que ambos os autores se interessam muito mais pelas qualidades positivas da memória, por sua estabilidade, continuidade e pelo papel que ela desempenha na coesão social do que por aquilo que ela representa de disputas, de violência simbólica e de relações conflituosas de poder, que pensamos ser inseparável do trabalho de coletivização/oficialização de uma memória:

Na abordagem durkheimiana, a ênfase é dada à força quase institucional dessa memória coletiva, à duração, à continuidade e à estabilidade. Assim também Halbwachs, longe de ver nessa memória coletiva uma imposição, uma forma específica de dominação ou violência simbólica, acentua as funções positivas desempenhadas pela memória comum, a saber, de reforçar a coesão social, não pela coerção, mas pela adesão afetiva ao grupo, donde o termo que utiliza, de "comunidade afetiva" (POLLACK, 1989, p. 3-15).

As batalhas pela memória que acompanhamos na sociedade argentina contrariam tal abordagem, na medida em que ratificam que o trabalho de construção social da memória, do qual o cinema participa ativamente, se dá de forma conflituosa. O predomínio de determinada memória pressupõe a articulação de um trabalho de enquadramento que, por vezes, oblitera memórias alternativas e deixa em seu rastro zonas de elipses, recalques e esquecimentos.

O cinema conjuga os níveis da memória que, desde Proust, ficaram conhecidas como memória involuntária e memória voluntária, sendo esta última identificada aqui com a lembrança, que pressupõe um operativo de organização consciente da experiência numa temporalidade. Bosi (apud ALBUQUERQUER Jr, 2007, p. 202), dissertando acerca desse nível da memória, observa que lembrar "não é reviver, mas refazer, reconstruir, com imagens e ideias de hoje, as experiências do passado". Isto significa aceitar que as configurações do presente, além de serem imprescindíveis ao ato de lembrar, acabam por determinar o conteúdo da lembrança, porque sua evocação é um trabalho que se opera a partir do tempo presente, em função e sob pressão dele. Identificamos esse pressuposto também em Pollack (1992, p. 204):

A memória também sofre flutuações que são função do momento em que ela é articulada, em que ela está sendo expressa. As preocupações do momento constituem um elemento de estruturação da memória. Isso é verdade também em relação à memória coletiva [...].

Quando acompanhamos tais flutuações no tipo de memória construída pelo cinema argentino aqui objetivado, vemos, por exemplo, que a alternância entre um cinema de comoção (La História Oficial, lançado em 1985, de Luiz Puenzo, e La Noche de los Lápices,

\section{GANPHLAC}

Revista Eletrônica da ANPHLAC, ISSN 1679-1061, №. 18, p. 287-304, jan./jul. 2015. 
de 1986, dirigido por Hector Oliveira) e um cinema melancólico (Juan Como si nada Hubiera Sucedido, Un Muro de Silencio e No te Muera Sin Decirme Adonde Vas) acompanha as conjunturas políticas que têm determinado a postura do Estado com relação aos crimes praticados durante o último regime militar. ${ }^{16} \mathrm{O}$ cinema aí, no entanto, não apenas responde às condições encontradas, mas também as engendra. Tanto é que, desde a abertura democrática, os filmes talvez tenham sido o instrumento mais acionado na batalha por definir o que deveria ser lembrado (os crimes da ditadura contra pessoas) e o que deveria ser esquecido (a conjuntura anterior ao golpe de 1976, à guisa de exemplo).

No nível da memória voluntária, o tempo vivido se torna suscetível aos imperativos do presente, posto ser este quem o convoca. O passado aí, devidamente demarcado, é um novo tempo impregnado de vivência. É essa memória, segundo Albuquerque Júnior (2007, p. 202),

[...] que fixa as experiências e inventa as tradições, portanto, [...] ela é produto do trabalho e da inteligência com que o narrador incorpora sempre o acontecimento na sua vida, e o narra como sua experiência individual. Ela é, pois, um ponto de vista sobre o passado.

Diferentemente, o nível involuntário da memória, comumente identificado como reminiscência, não resulta da evocação consciente do indivíduo nem requer um esforço de elaboração. Ela se baseia na semelhança profunda entre dois momentos, na fusão de sensações presentes e passadas, que remete a uma identidade entre elas - seja uma sensação comum aos dois momentos (passado e presente) ou uma qualidade comum às duas sensações. Nela, o passado em si fulgura veloz e vivo no presente e nos deixa a desconfiança de que ambos os

\footnotetext{
${ }^{16}$ Chamamos de "Cinema de Comoção" os filmes estreados no contexto da abertura democrática, os quais buscavam capturar o espectador mediante uma identificação provocada pela narrativa comovente das desventuras vivida pelas vítimas da ditadura (AMADO, 2009). Aí enquadramos os filmes La Noche de los Lápices e La Historia Oficial. O primeiro narra a história real dos alunos secundaristas de La Plata que, em 1976, depois de participarem de uma manifestação por passe estudantil, foram presos, torturados e desaparecidos; o segundo, ganhador de um Oscar de melhor filme estrangeiros, enquadra o drama da mãe adotiva de um bebê supostamente apropriado de pais desaparecidos. Ambos os filmes participam ativamente do clima de comoção coletiva que se via quando da volta da democracia e julgamento às Juntas Militares pelos crimes cometidos. Adiante, em função das leis alfonsinistas que paralisaram os inquéritos e absolveram os militares de escalões inferiores, bem como dos indultos menemistas, a sociedade argentina atravessou estágios de melancolia (que freudianamente traduz a impossibilidade de enlutar seus mortos), um letárgico e outro combativo, a partir de 1995 (GUNDERMAN, 2007). Chamamos de cinema melancólico os filmes que expressam esses estágios, tais quais Juan Como si Nada Hubiera Sucedido, Un Muro de Silencio - vide nota n. ${ }^{\circ}$ 9.
}

\section{GANPHLAC}

Revista Eletrônica da ANPHLAC, ISSN 1679-1061, №. 18, p. 287-304, jan./jul. 2015.

http://revista.anphlac.org.br/ 
tempos não se sucedem, mas coexistem, e que a reminiscência é prisioneira do tempo presente.

Nesse nível da memória estaria, segundo Benjamin, a verdadeira imagem do passado, a qual perpassa veloz e só se deixa capturar como imagem quando é reconhecida. O filósofo serve-se dela na composição da noção de história com a qual denuncia o cientificismo dos historicistas, cujos procedimentos os colocavam em empatia com o status quo, com o vencedor. Por isso, para Benjamin (1994, p. 224), "articular historicamente o passado não significa conhecê-lo 'como ele de fato foi'. Significa apropriar-se de uma reminiscência, tal como ela relampeja num momento de perigo".

Segundo Deleuze (2010, p. 56), a memória involuntária “interioriza o contexto, torna o antigo contexto inseparável da sensação presente". Mas o essencial aí não é a identidade nem a semelhança entre esses dois momentos, entre as duas sensações, mas sim a interiorização da diferença. E é aí que a reminiscência se faz semelhante à arte: "ela toma 'dois objetos diferentes'[...] e envolve um no outro, faz da relação dos dois alguma coisa de interior" (DELEUZE, 2010, p. 57). Esse nível da memória revela também uma dependência em relação aos quadros sociais do presente.

$\mathrm{O}$ atrelamento da memória aos signos do presente torna claro que seu procedimento envolve, necessariamente, seleções, como assinala Todorov (1995, p. 16): “Conservar sin elegir no es una tarea de la memoria". ${ }^{17}$ Com isso, compreendemos que não há memória sem esquecimento e que seu uso político se inscreve nas disputas pela gestão do que deve ser lembrado e esquecido. Na década de 90, na Argentina, o reacender dos grupos de direitos humanos contra a oficialização alfonsinista e menemista da impunidade colocava em curso o direito que têm todas as coletividades de conhecer e dar a conhecer sua própria história. Sobretudo ali, por ser de natureza excepcional o referente dessa memória - a sorte vivida pelas vítimas da ditadura -, é compreensível que o direito tenha se convertido em dever. Isso, no entanto, não determina, não automatiza nem torna previsível a utilização que, subsequentemente, grupos políticos, ideológicos e o próprio Estado farão dessa memória.

Como lugar/produção de memória e engenho de representação social visceralmente ligado à industria e à economia, o cinema se torna especialmente sujeito àquelas intervenções, em face da relação de dependência que boa parte das produções tem com os financiamentos

\footnotetext{
17 "Conservar sem escolher não é uma tarefa da memória."

\section{GANPHLAC}


estatais e com a iniciativa privada. Por vezes, essa dependência resvala numa espécie de submissão à ideologia dominante. Na Argentina, entre fins da década de 80 e meados da década de 90, o cinema mostrou ser uma importante ferramenta de luta e de poder quando foi erguido contra os abusos de esquecimento operados pelo Estado. Os filmes aí localizados posicionaram-se numa espécie de campo de embate, interpelando a sociedade para uma tomada de atitude contra o esquecimento, e o fizeram por meio da adoção de uma linguagem que forçava o espectador à reflexão, ao tempo em que expunha, como estágio a ser superado ou não, o substrato melancólico presente.

No entanto, em tempos recentes, em que o Estado deixou de ser o "inimigo da memória" para ser seu "usurpador", esse cinema estreitou seu vínculo com o governo justicialista, tendo em vista que os autores se identificam com seu projeto político e se afinam ideologicamente com ele. Talvez por isso, vem se tornando comum no cinema o ressurgir do guerrilheiro peronista de esquerda (que esse mesmo cinema havia escondido e homogeneizado sob a categoria desaparecido), agora representado no bojo de uma memória afirmativa e humanizada. Tais construções o distanciam do tipo subversivo que habitava o imaginário coletivo do contexto anterior ao golpe militar, como faz, por exemplo, Más que um Hombre (2007), de Dady Brieva e Gerardo Vallina, entre outros. ${ }^{18}$ Mas, contemporaneamente, é possível também vislumbrar o surgimento de uma cinematografia independente, aparentemente desvencilhada desses projetos políticos, da qual é possível extrair uma leitura que ironiza (e desacredita) as operações da memória, como é o exemplo do

\footnotetext{
${ }^{18}$ A narrativa de Más que un hombre remete à Argentina de 1977, um ano após a instauração da ditadura militar, em que se intensificou a caçada aos chamados subversivos, e conta a história do personagem Telmo, um costureiro homossexual que assume a tarefa de esconder na casa onde mora com sua mãe o jovem guerrilheiro Olaf, quando este fugia de uma operação dos militares. A partir daí, o jovem guerrilheiro é envolvido num jogo de sedução com Telmo, e situações cômicas são suscitadas na medida em que a imagem estereotipada do revolucionário sisudo e "machão" é desconstruída na direção de um romance sublimado com o costureiro. Dentre outros efeitos, o filme reveste a imagem do guerrilheiro peronista com uma sensibilidade humanizadora impensável em outros contextos.
}

\section{CANPHLAC}

Revista Eletrônica da ANPHLAC, ISSN 1679-1061, №. 18, p. 287-304, jan./jul. 2015. 
filme Querida voy a comprar cigarrillos y vuelvo (2011), de Gastón Duprat e Mariano Cohn. ${ }^{19}$

O exercício da memória na Argentina, que faz do passado um privilegiado objeto de disputas, conforme acompanhamos a partir da abertura democrática, remete-nos ainda à tipologia nietzschiana que classifica as formas de uso (e abuso) da história. Segundo ela, a história é necessária ao vivente em três aspectos: "conforme ele age e aspira, preserva e venera, sofre e carece de libertação" (NIETZSCHE, 2003, p. 17-18). Esses três aspectos correspondem a três tipos de história - a monumental, a antiquária e a crítica. Tais tipos dizem respeito a diferentes modos de vida, cada um dos quais deve desenvolver-se apenas no solo e clima que lhe correspondem, sob a pena de degenerar-se em semente nociva:

Se o homem que quer criar algo grandioso precisa efetivamente do passado, então ele se apodera dele por intermédio da história monumental; em contrapartida, quem quer fincar o pé no familiar e na veneração do antigo cuida do passado como o historiador antiquário; e somente aquele que tem o peito oprimido por uma necessidade atual e que quer a qualquer preço se livrar do peso em suas costas carece de uma história crítica, isto é, de uma história que julga e condena (NIETZSCHE, 2003, p. 24-25).

Alguns problemas dos quais padece um povo decorrem da transplantação incoerente desses modos - "o crítico sem necessidade, o antiquário sem piedade, o conhecedor do grande sem o poder do grande" (NIETZSCHE, 2003, p. 24-25). É pertinente especular esses modos de vida e relacioná-los com as distintas atitudes do cinema argentino voltado ao passado, de forma que se possam perscrutar as perspectivas de história sob as quais os filmes integram o registro da experiência passada à vida e as urgências (ou os projetos) que provocam a releitura dessas experiências. Por exemplo, nos filmes do americano Griffith, conforme crítica de Eisenstein (2002), vigora uma perspectiva de História Monumental, que é aquela que recorta os grandes acontecimentos do passado e os eterniza. $\mathrm{O}$ inconveniente nessa noção de história

\footnotetext{
${ }^{19}$ A produção Querida Voy a Comprar Cigarrillos y Vuelvo, de Gastón Duprat e Mariano Cohn, desencontra-se de todos os filmes sobre o passado recente argentino, porque, apesar de ser construída nos moldes de uma comédia, a sua pulsão é da construção de uma crítica social aos atos de memórias que caracterizam a sociedade. Pensado a partir de um conto homônimo do escritor Alberto Laiseca, o filme recusa e critica a possibilidade de intervenções no passado e as atitudes que dela decorrem, e desfere ironias sarcásticas aos sujeitos e instituições que, na Argentina, detêm o privilégio sobre os discursos que se apropriam do passado.
}

\section{GANPHLAC}

Revista Eletrônica da ANPHLAC, ISSN 1679-1061, №. 18, p. 287-304, jan./jul. 2015. 
estaria no fato de tomar os fenômenos separados de qualquer causa, como efeitos em si, o que levava o cineasta russo a identificá-la como uma concepção burguesa de história, para a qual os procedimentos do cinema de Griffith davam provas.

Por sua vez, o cinema argentino que trabalha a memória da repressão se aproxima do registro de uma História Crítica, na medida em que posiciona continuamente o passado num banco de réus. E nesse dizer, o advérbio "continuamente" evidencia a percepção de que a cristalização do passado - a remontagem melancólica no presente dos embates de outrora, conforme acompanhamos no interior desse cinema político -, parece fundir a perspectiva crítica com a do historiador antiquário referido na tipologia nietzschiana. Não obstante, na medida em que identificamos um silêncio na abordagem do último peronismo (pré-golpe de 76) em prol da imagem de sua primeira fase, quiçá como estratégia de retomada de um projeto de nação outrora abortado, podemos perceber que esse cinema tampouco escapa da perspectiva de uma História Monumental.

O modo como o cinema político argentino lida com o passado, bem como a sociedade, coloca para nós, historiadores, intrigantes questões sobre os limites que devem (ou não) ser colocados ao imperativo da lembrança, do não esquecimento das feridas abertas no passado. Por exemplo, o perigo apontado por Nietzsche de que o excesso de memória pode levar uma época a arrogar-se de possuir a mais alta virtude e a mais elevada justiça que qualquer outro tempo é bastante visível no caso argentino, sobretudo nos procedimentos de HIJOS, Madres e outros grupos, e na atitude do governo kirchnerista, quando faz do dever de memória uma política de Estado. No entanto, sem contradizer a coerência dos argumentos do filósofo, no caso aqui objetivado, a conjugação desses elementos - lembranças \& esquecimento - deve ser feita à luz da especificidade da história argentina no século XX. Se assim fizermos, podemos talvez inferir que a sucessão de golpes militares que assolaram o país, ainda que intercalados por democracias (mal sucedidas, no entanto), significa muito mais o sintoma de uma amnésia coletiva do que o contrário. Em segundo lugar, se considerarmos a especificidade das feridas abertas pela última ditadura militar (que significou o clímax daquela sucessão) - os milhares de desaparecidos como causa da abertura de um vazio na vida daqueles diretamente afetados (familiares e outros) - vamos compreender que a memória dos ressentimentos é que deve ser esquecida; mas os acontecimentos devem ser lembrados, quiçá como estratégia de estancar aquela tendência à repetição.

\section{GANPHLAC}

Revista Eletrônica da ANPHLAC, ISSN 1679-1061, №. 18, p. 287-304, jan./jul. 2015. 


\section{Referências bibliográficas:}

ALBUQUERQUE Jr, Durval Muniz de. História: a arte de inventar o passado. Ensaios de teoria da história. Bauru, SP: EDUSC, 2007.

ALMEIDA, Milton José de. Cinema: arte da memória. Campinas: Autores Associados, 2009.

AMADO, Ana. La imagen justa: Cine argentino y politica (1980-2007). Buenos Aires: Colihue, 2009.

BENJAMIN, W. Magia e técnica, arte e política: obras escolhidas Vol. 1. Trad. Sérgio Paulo Rouanet. São Paulo: brasiliense, 1994.

Brasiliense, 1984.

Origem do drama barroco alemão. Trad. Sérgio Paulo Rouanet. São Paulo:

CHARTIER, Roger. A história cultural: entre práticas e representações. Lisboa: DIFEL, 1990.

DELEUZE, Gilles. Proust e os signos. Trad. Antonio C. Piquet \& Roberto Machado. Rio de Janeiro: Forense Universitária, 2010.

EISENSTEIN, Sergei. A forma do filme. Trad. Teresa Ottoni. Rio de Janeiro: Jorge Zahar Editora, 2002.

FERRO, Marc. Cinema e história. Rio de Janeiro: Paz e Terra, 1992.

GAGNEBIN, Jeanne M. História e narração em Walter Benjamin. São Paulo: Perspectiva, 2007.

GOCIOL, Judith; INVERNIZZI, Hernán. Cine y ditadura: la censura al desnudo. Buenos Aires: Capital intelectual, 2006.

GOMES, Salatiel R. História e cinema: sertão e redenção em Deus e o Diabo na Terra do Sol. São Paulo: Annablume, 2011.

Memória e cinema: sobre a dívida solidária do passado em Aparecidos (2007). Revista Contemporâneos, n. ${ }^{\circ} 12$, nov. a abr. de 2015.

GUNDERMAN, Christian. Actos melancólicos. Formas de resistência en la posdictadura argentina. Rosario: Beatriz Viterbo, 2007.

KRACAUER, Sigfried. De Caligari a Hitler: Uma história psicológica do cinema alemão. Rio de Janeiro: Jorge Zahar, 1988.

\section{GANPHLAC}

Revista Eletrônica da ANPHLAC, ISSN 1679-1061, №. 18, p. 287-304, jan./jul. 2015. 
KRIGER, Clara. Cine y peronismo: el estado em escena. Buenos Aires: Siglo Veintiuno Editores, 2009.

NIETZSCHE, Friedrich. Segunda consideração intempestiva: da utilidade e desvantagem da história para a vida. Rio de Janeiro: Relume Dumará, 2003.

NÓVOA, Jorge.Cinematógrafo: laboratório da razão poética e do "novo" pensamento. In: NÓVOA, Jorge; FRESSATO, Soleni B; FEIGELSON, Kristian (Orgs.). Cinematógrafo: um olhar sobre a história. Salvador/São Paulo: EDUFBA/UNESP, 2009.

POLLACK, Michel. Memória e identidade social. Estudos históricos, Rio de Janeiro, vol. 5, n. 10, p. 204, 1992. p. 3-15, 1989.

Memória, esquecimento, silêncio. Estudos históricos. Rio de Janeiro, vol. 2, n. 3,

RICOEUR, Paul. A memória, a história, o esquecimento. Trad. Alain François et al. Campinas: Unicamp, 2007.

ROUANET, Sérgio Paulo. Édipo e o anjo: itinerários freudianos em Walter Benjamin. Rio de Janeiro: Tempo Brasileiro, 1990.

SARLO, Beatriz. Tempo passado: cultura da memória e guinada subjetiva. Trad. Rosa Freire d' Aguiar. São Paulo/Belo Horizonte: Cia das Letras/UFMG, 2007.

SORLIN, Pierre. Sociologia del cine. México: FCE, 1985.

STAM, Robert. Introdução à teoria do cinema. Campinas: Papirus, 2003.

TODOROV, Tzvetan. Los abusos de la memoria. Buenos Aires: Paidós Ibérica, 1995.

\section{Filmes citados}

APARECIDOS. Direção de Paco Cabezas. Espanha/Argentina, 2007. 107 minutos, colorido.

CAUTIVA. Direção de Gastón Biraben. Argentina, 2003. 115 minutos, colorido.

GANAMOS LA PAZ. Direção de Francisco Javier Mendonza. Argentina, 1976. 28 minutos, colorido. Documentário.

JUAN COMO SI NADA HUBIERA SUCEDIDO. Direção de Carlos Echeverria. Argentina, 1987. 160 minutos. Preto e branco. Documentário.

LA HISTORIA OFICIAL. Direção de Luis Puenzo. Argentina, 1985. 110 minutos, colorido.

LA NOCHE DE LOS LÁPICES. Direção de Héctor Oliveira. Argentina, 1986. 106 minutos, colorido.

\section{GANPHLAC}

Revista Eletrônica da ANPHLAC, ISSN 1679-1061, №. 18, p. 287-304, jan./jul. 2015. 
MÁS QUE UN HOMBRE. Direção de Dady Brieva e Gerardo Vallina. Argentina, 2007. 93 minutos, colorido.

NO TE MUERAS SIN DECIRMES ADONDE VAS. Direção de Eliseo Subiela. Argentina, 1995. 120 minutos, colorido.

O ETERNO JUDEU. Alemanha, 1940. 65 minutos, preto e branco. Documentário.

QUERIDA VOY A COMPRAR CIGARRILLOS Y VUELVO. Direção de Mariano Cohn e Gastón Duprat. Argentina, 2011. 80 minutos, colorido.

TRIUNFO DA VONTADE. Direção de Leni Riefenstahl. Alemanha, 1936. 110 minutos, preto e branco. Documentário.

UN MURO DE SILENCIO. Direção de Lita Stantic. Produção de Dolly Pussi e Pablo Rovito. Buenos Aires, 1993. 107 minutos. Colorido.

\section{CANPHLAC}

Revista Eletrônica da ANPHLAC, ISSN 1679-1061, Nº. 18, p. 287-304, jan./jul. 2015. 